\title{
Process Design of Microbiological Chitin Extraction
}

\author{
BUDIASIH WAHYUNTARI ${ }^{1 *}$, JUNIANTO², AND SISWA SETYAHADI ${ }^{1}$
}

\begin{abstract}
'Center for Bioindustrial Technology, Laboratoria Pengembangnan Teknologi Agro-Biomedika, Badan Pengkajian dan Penerapan Teknologi, Pusat Penelitian Ilmu Pengetahuan dan Teknologi, Serpong, Tangerang 15314 , Indonesia; ${ }_{2}^{2}$ Faculty of Fishery and Marine Sciences, Universitas Padjajaran, Jalan Raya Jatinangor Km 21, Sumedang 45363, Indonesia
\end{abstract}

\begin{abstract}
Chitin extraction from shrimp shells involves two processing steps, these are the deproteination and demineralization process. The aim of this experiment was to compare the order of the chitin extraction process. The first experiment was deproteination of fresh shrimp shells followed by demineralization process and the second one was demineralization of fresh shrimp shells followed by deproteination. Bacillus licheniformis F11.1, a proteolytic producing bacterium, was used for the deproteination process. Lactobacillus acidophilus FNCC116, a lactic acid bacterium, was used for the demineralization process. The deproteination was done in a 1 liter fermenter jar at $55^{\circ} \mathrm{C}, 250 \mathrm{rpm}$ and $2.5 \mathrm{vvm}$ aeration for $60 \mathrm{~h}$. The demineralization was done in the same size fermenter at $30^{\circ} \mathrm{C}$ and $50 \mathrm{rpm}$ agitation for $48 \mathrm{~h}$. The experimental results showed that demineralization followed by the deproteination process resulted in a better chitin yield than when the process was conducted in the opposite order. The first process reduced $47.37 \%$ protein and $50.23 \%$ ash, whereas the second process reduced $79.61 \%$ protein and $88.65 \%$ ash.
\end{abstract}

Key words: microbiological chitin extraction, deproteination, demineralization

Ekstraksi kitin terdiri atas dua tahap proses, yaitu proses deproteinasi dan demineralisasi. Tujuan penelitian ini membandingkan urutan tahapan proses ekstraksi kitin dari kulit udang. Percobaan pertama adalah deproteinasi kulit udang segar dilanjutkan dengan demineralisasi kulit udang yang telah dideproteinasi. Percobaan kedua adalah demineralisasi kulit udang segar dilanjutkan dengan deproteinasi kulit udang yang telah didemineralisasi. Bacillus licheniformis F11.1, penghasil enzim proteolitik digunakan dalam proses deproteinasi. Lactobacillus acidophilus FNCC116, penghasil asam laktat digunakan untuk proses demineralisasi. Proses demineralisasi dilakukan dalam tabung fermentor 1 liter, pada $55^{\circ} \mathrm{C}, 250 \mathrm{rpm}$, aerasi $2.5 \mathrm{vvm}$ selama 60 jam. Proses demineralisasi dilakukan dalam fermentor yang berukuran sama pada $30^{\circ} \mathrm{C}, 50 \mathrm{rpm}$ selama 48 jam. Hasil percobaan menunjukkan bahwa proses demineralisasi dilanjutkan dengan deproteinasi menghasilkan produk kitin yang lebih baik daripada proses dengan urutan sebaliknya. Percobaan pertama berhasil menurunkan kadar protein sebesar $47.37 \%$ dan abu sebesar $50.23 \%$; sedangkan proses kedua menurunkan kadar protein sebesar $79.61 \%$ dan abu $88.65 \%$.

Kata kunci: ekstrasi kitin secara mikrobiologi, deproteinasi, demineralisasi

Chitin (poly -(1-4)-N-acetyl-D-glucosamine) is a linear polysaccharide and the second most abundant natural polymer after cellulose. In nature chitin appears as ordered crystalline microfibrils forming structural components in the exoskeleton of arthropods or in the cell walls of fungi and yeast (Rinaudo 2006). Chitin and its derivatives have been used in many applications including pharmaceuticals, textile, food, and cosmetics.

The primary source of chitin production is from marine crustacean shell waste. Shrimp shells are predominantly composed of chitin in a complex binding to $10-20 \%$ calcium and $30-45 \%$ protein (Rao and Stevens 2005). Indonesia is one of the main shrimp producing and exporting countries. In 2007, 160797 tons shrimps was exported and $90 \%$ of it was in the form of frozen headless shelled ones. As a consequence, there has been a lot of shell waste from frozen shrimp industries. Shrimp shell waste consists

*Corresponding author, Phone: +62-21-811153294 Fax:+62-21-7560536, Email: budiasih_solichin@yahoo.com of $45 \%$ of the whole shrimps (Dhewanto and Kresnowati 2002), therefore in 2007, the amount of shell waste was about 100.188 tons, most of which has only been used as animal feed.

There has been some chitin production in Indonesia, however, all of it is produced using a chemical process. The chemical method of chitin extraction from the shells involves alkali deproteination using $2.75 \mathrm{M}$ $\mathrm{NaOH}$ and acid demineralization using $1 \mathrm{M} \mathrm{HCl}$. The chemical process may cause hydrolysis of the polymer and inconsistence of some physical properties, however, the main concern using the chemical process is the use of harsh chemicals at high temperature which causes corrosion of the equipment and environmental problems of the waste disposal (Beaney et al. 2005). To solve these problems, some biological processes including enzymatic, microbiological as well as chemical-biological combinations have been studied. Some experiments of chitin extraction were done by combining chemical demineralization and enzymatic or microbiological deproteination (Gagne and Simpson 1993; Bustos and Healy 1994; Oh et al. 2000; 
Yang et al. 2000). Other experiments used single strain or mixed cultures of microorganisms for demineralization and deproteination in a separate process or in a one step operation. Rao et al. (2000) used Lactobacillus plantarum 541 for the demineralization and deproteination of shrimp biowaste with addition of organic acids (lactic, acetic and citric acid) and inorganic acid ( $\mathrm{HCl})$. A mixed cultures consisting of $L$. plantarum, L. salivarius, Streptococcus faecium, and Pediococcus acidilacti was used by Healy et al. (2003) to extract chitin from prawn shell waste. Rao and Stevens (2006) conducted a one step chitin extraction process using $L$. plantarum 541 with addition of glacial acetic acid to adjust the $\mathrm{pH}$ of the shrimp waste down to $\mathrm{pH} 6$ at the beginning of the process. The wild type of the same bacterium (Bacillus licheniformis F11) used in this experiment was used for deproteination of shrimp shells by Daum et al. (2007) in combination with different species of Lactobacillus for demineralization.

The aim of these experiments was to find the succession of microbiological deproteination and demineralization in chitin extraction of shrimp shell waste that would render the higher chitin yield. The first experiment was deproteination of fresh shrimp shells followed by the demineralization process. The second experiment was demineralization of fresh shrimp shells followed by deproteination. $B$. licheniformis F11.1, a proteolytic, chitinase-defficient bacterium, was used for the deproteination process, and Lactobacillus acidophilus FNCC-116, a lactic acid bacterium, was used for the demineralization process.

\section{MATERIALS AND METHODS}

Shrimp Shells and Microorganisms. Headless shrimp shells of Penaeus vannamei were obtained from a frozen shrimp processing company "PT Wirontono Baru" North Jakarta, Indonesia. The shells were washed and disintegrated into size of $5-10 \mathrm{~mm}$ and kept at $-20{ }^{\circ} \mathrm{C}$ before being used for the experiments.

B. licheniformis F.11-1 used for removing protein from shrimp shells was isolated from shrimp shell waste of PT Laura Indo, a frozen shrimp processing company, Palembang, Sumatera, Indonesia. The bacterium was isolated and identified by Waldeck et al. (2006). Recently the bacterium was genetically modified (B. licheniformis F.11-pga) by Hoffman et al. (2010). The stock culture was kept in $10 \%$ glycerol and $10 \%$ skimmed milk were stored in a deep freezer (NU6520 E, NUAIR, Plymouth MN55447, USA) at $-80^{\circ} \mathrm{C}$.

L. acidophilus FNCC 116, a lactic acid producing bacterium, was used for the demineralization process.
The bacterium was obtained from the Food Nutrition Culture Collection of the Faculty of Agricultural Technology, University of Gadjah Mada, Yogyakarta, Indonesia. The stock cultures was kept in $10 \%$ glycerol and $10 \%$ skimmed milk and were stored in a deep freezer (NU-6520E, NUAIR, Plymouth MN55447, USA) at $-80^{\circ} \mathrm{C}$.

Fermentation Demineralization Process. Refreshing of the frozen stock culture was conducted by transferring $1 \mathrm{~mL}$ stock culture into $9 \mathrm{~mL}$ of sterile De Man Rogosa and Sharpe (MRS) broth, which was incubated at $37{ }^{\circ} \mathrm{C}$ for $24 \mathrm{~h}$. To prepare a starter inoculums, $10 \mathrm{~mL}$ refreshed culture were transferred into $90 \mathrm{~mL}$ MRS broth in a $250 \mathrm{~mL}$ Erlenmeyer flask and incubated at $37^{\circ} \mathrm{C}$ until the optical density reached 0.85 at wavelength of $600 \mathrm{~nm}$ (U-2001, Hitachi Instrument Inc, USA), which equals a cell concentration of about $1 \times 10^{9} \mathrm{~mL}^{-1}$. Based on previous studies, the optimum demineralization condition is at $30 \pm 2{ }^{\circ} \mathrm{C}$ and $50 \mathrm{rpm}$ agitation (Junianto et al. 2009). Three hundred grams frozen shrimp shell waste $(69.5 \%$ moisture) were added to $900 \mathrm{~mL}$ liquid media and 100 $\mathrm{mL}$ starter inoculums. $100 \mathrm{~mL}$ medium contained $60 \mathrm{mg}$ glucose and $0.5 \mathrm{mg}$ yeast extract. The $\mathrm{pH}$ was adjusted to $\mathrm{pH} 7.0$. The fermentation was done at $37^{\circ} \mathrm{C}$ and $50 \mathrm{rpm}$ agitation for $48 \mathrm{~h}$. When the demineralization process was completed the shells were separated from the broth and washed with running water until the washed water became neutral $(\mathrm{pH} 7.00)$ and drained. The demineralized shells were then kept in Freezer $-20{ }^{\circ} \mathrm{C}$ (Derby F 20U, Denmark) for the following process. Demineralization efficiency is defined as efficiency of ash removal that calculated as follows initial $\%$ ash subtracted by $\%$ ash after the process devided by initial $\%$ ash multiply by $100 \%$.

Deproteination Process. The frozen stock culture of $B$. licheniformis F11.1 was refreshed in Luria Bertani (LB) broth. The culture was incubated in a shaking incubator (Lab-Therm, Kühner, Switzerland) at $55^{\circ} \mathrm{C}$ and $180 \mathrm{rpm}$ for $6 \mathrm{~h}$ or until the optical density of the culture reached 0.9 which, based on previous experiments, equals a cell density of about $1 \times 10^{9} \mathrm{CFU}$ $\mathrm{mL}^{-1}$ (Junianto et al. 2009). Each $100 \mathrm{~mL}$ fermentation medium contained $0.5 \mathrm{~g} \mathrm{KH}_{2} \mathrm{PO}_{4}, 0.5 \mathrm{~g} \mathrm{NaCl}, 0.5 \mathrm{~g}$ yeast extract $0.05 \mathrm{~g} \mathrm{MgSO}_{4}$ and $0.1 \mathrm{~g} \mathrm{CaCl}_{2}$. Two hundred $\mathrm{mL}$ of inoculums were added into $300 \mathrm{~g}$ of shrimp shells in $800 \mathrm{~mL}$ medium. The fermentation was carried out at $55^{\circ} \mathrm{C}, 2.5 \mathrm{vvm}$ aeration and $250 \mathrm{rpm}$ agitation for $60 \mathrm{~h}$ and the $\mathrm{pH}$ was maintained in a range of 7.8-8.2. After the deproteination process was completed, the shells were separated from the broth, washed, drained and kept at $-20^{\circ} \mathrm{C}$ for the following process. Deproteination 
efficiency is defined as efficiency of protein removal that calculated as follows initial \% protein subtracted by $\%$ protein after the process devided by initial $\%$ protein multiply by $100 \%$.

All fermentations were conducted in a custom made fermentor which consisted of a $2 \mathrm{~L}$ glass cylinder jar, equipped with a Janke and Kunkel rod agitator for agitation, a compressor connected to a LKB-Bromma (Sweden) flow meter for aeration and heated by a coil in the fermentor that was connected to a water bath for temperature control. The shrimp shells were not sterilized prior to fermentation, since the process is intended for small scale industries that mostly do not have sterilization facilities. Based on preliminary experiment, the amount of the inoculums of $10^{9} \mathrm{CFU}$ $\mathrm{mL}^{-1}$ was able to avoid overgrown of contaminated bacteria.

Analytical Procedures. Moisture content was determined by heating samples at $110^{\circ} \mathrm{C}$ in a "Kett" infrared moister meter model F-1A (Tokyo, Japan). Ash content was determined after combustion of $5 \mathrm{~g}$ dried sample in a crucible at $600{ }^{\circ} \mathrm{C}$ for $4 \mathrm{~h}$ (AOAC 1984) in a muffle furnace Fischer Scientific model 182A. Insoluble protein content of the shrimp shells and fermented solid samples was solubilized using $1 \mathrm{M}$ $\mathrm{NaOH}$. A half gram sample was added to $7.5 \mathrm{~mL}$ of $1 \mathrm{M}$ $\mathrm{NaOH}$ and incubated for $24 \mathrm{~h}$. The protein content of the supernatant was measured according to the Lowry method (1951) using Bovine serum albumin fraction IV (Sigma, St Louis, USA) as a standard. Glucose was analyzed using method of Miller (1959) and lactic acid content was analyzed using HPLC (Merck-Hitachi, Tokyo, Japan), Aminex HPX-87H (300mm x 7,8mm) column, at $65^{\circ} \mathrm{C}$ (L-5025-Column Thermostat, Merck, Tokyo, Japan), isocratic mobile phase of $0.005 \mathrm{~N}$ $\mathrm{H}_{2} \mathrm{SO}_{4}$ with a flow rate of $0.6 \mathrm{~mL} \mathrm{~min}{ }^{-1}$ (L-6200APump, Merck-Hitachi, Tokyo, Japan), Differential Refractometer detector RI-71 (Merck, Tokyo, Japan). The Glucose Standard used was 1\% Glucose (SigmaAldrich, St Louis, USA) and the lactic acid standard was 10\% L-Lactic Acid (Oxoid, Hampshire, England). The protease activity in fermented broth was assayed using azocasein as a substrate according to the method described by Waldeck et al. (2006). One unit was defined as the amount of enzyme releasing $1 \mathrm{~mol}$ azocasein per min under reaction conditions. The density of bacterial growth in fermentation broth was assayed after serial dilution by counting colony forming unit $\left(\mathrm{CFU} \mathrm{mL} \mathrm{mL}^{-1}\right)$ on MRS agar plate after incubation at $37^{\circ} \mathrm{C}, 24 \mathrm{~h}$ for L. acidophilus $\mathrm{FNCC} 116$ and on LB agar plate after incubation at $55^{\circ} \mathrm{C}, 24 \mathrm{~h}$ for B. licheniformis F11.1.

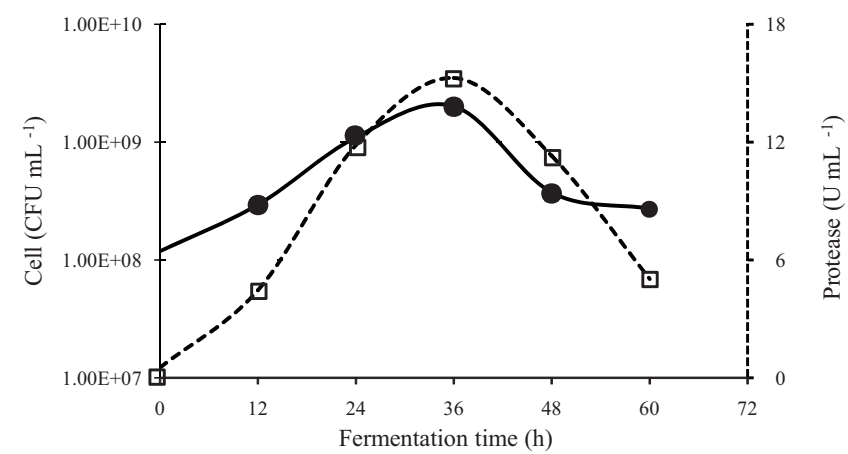

Fig 1 Deproteination process of fresh shrimp shell waste using Bacillus licheniformis F11.1. @, cell growth; $\square$, protease production.

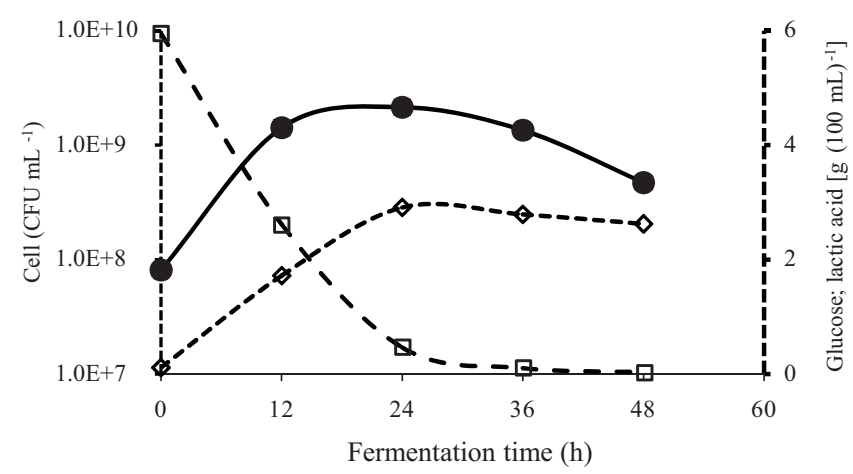

Fig 2 Demineralization of deproteinated shrimp shells using Lactobacillus acidophillus FNCC116. •, cell growth; $\square$, glucose consumption; $\diamond$, lactic acid production.

\section{RESULTS}

Deproteination Process of Fresh Shrimp Shell Waste using B. licheniformis F11.1. The process was carried out within $60 \mathrm{~h}$, maximum cell growth and proteolytic activity reached after $36 \mathrm{~h}$ of fermentation with the maximum amount of the cell was $2.02 \times 10^{9}$. Initial proteolytic activity was $0.52 \mathrm{U} \mathrm{mL}^{-1}$ and reached maximum activity of $15.27 \mathrm{U} \mathrm{mL}^{-1}$ after $36 \mathrm{~h}$ then the activity decreased down to 5.03 at the end of the process. During the deproteination process, protein content of the shell decreased from $19.56 \%$ down to $5.44 \%$ at the end of fermentation process (Fig 1).

Demineralization of Deproteinated Shrimp Shells using L. acidophillus FNCC116. The maximum cell amount was reached after $24 \mathrm{~h}$-fermentation, and almost all glucose was used and some of it was converted into lactic acid for $36 \mathrm{~h}$ of fermentation (Fig 2). The protein and ash content of the shrimp shells at the end of the deproteination of fresh shrimp shells followed by demineralization of the deproteinated shells are shown (Fig 3). The protein content of the shells was reduced from $19.56 \%$ to $5.44 \%$ at the end of deproteination process but then increased to $10.3 \%$ after demineralization process. During deproteination process the ash content was increased from $19.57 \%$ to 


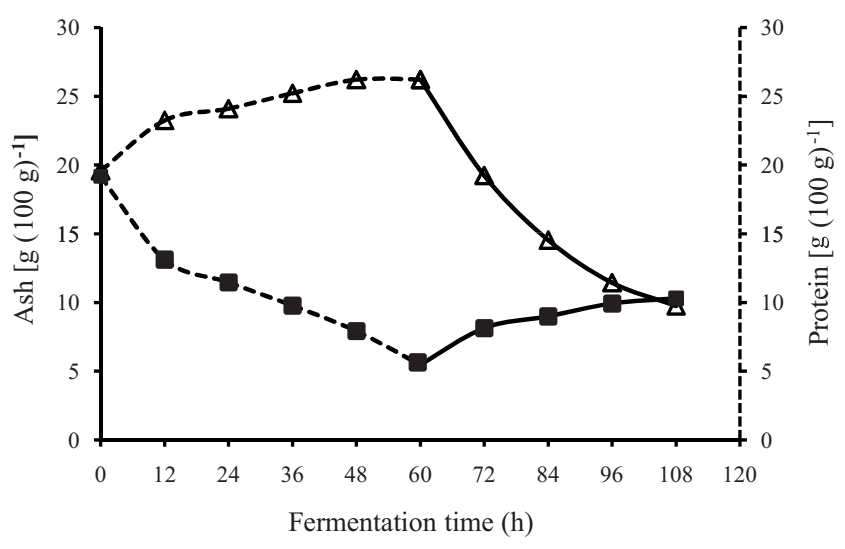

Fig 3 Ash and protein content in the shrimp shells during deproteination followed by demineralization process. ---, deproteination; _, demineralization; $\mathbf{\square}$, protein; $\triangle$, ash.

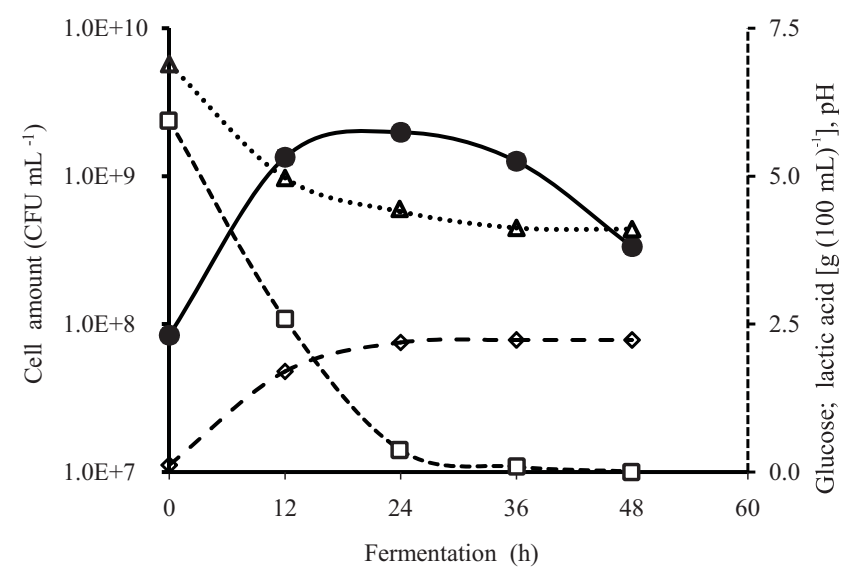

Fig4 Demineralization of fresh shrimp shell waste using Lactobacillus acidophillus FNCC 116. •, cell growth, $\square$, glucose consumption $\mathrm{g}(100 \mathrm{~mL})^{-1} ; \diamond$, lactic acid production $(\mathrm{g} 100 \mathrm{~mL})^{-1} ; \Delta, \mathrm{pH}$ value.

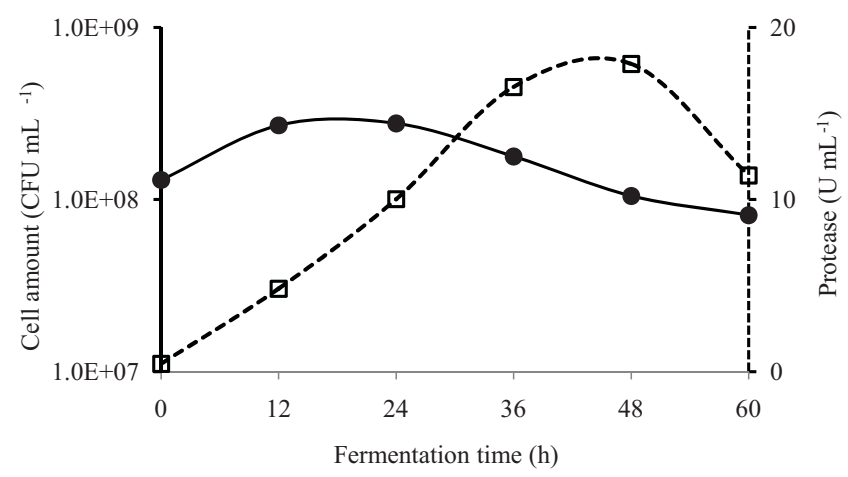

Fig 5 Deproteination of demineralized shrimp shells using Bacillus licheniformis F 11.1. •, cell growth; $\square$, protease production.

$26.21 \%$, but the ash content was reduced significantly down to $9.74 \%$ after demineralization proces.

Demineralization of Fresh Shrimp Shell Waste using L. acidophillus FNCC 11. Maximum cell amount, lactic acid production was reached after $24 \mathrm{hs}$ of fermentation. After demineralization process, the ash content of fresh shrimp shells was reduced from $19.57 \%$ down to $0.91 \%$, however the protein content was increased from $19.17 \%$ to $26.16 \%$ (Fig 4 ).

Deproteination of Demineralized Shrimp Shells using $B$. liheniformis $\mathrm{F}$ 11.1. The maximum cell amount was reached after 24 hs of fermentation $\left(2.77 \times 10^{8} \mathrm{CFU} \mathrm{mL}^{-1}\right)$, however the maximum proteolytic enzyme production reached after $48 \mathrm{hs}$ of fermentation. During deproteination process, the protein content of the shells decreased from $26.26 \%$ down to $4.0 \%$, whereas, the ash content increased from $0.92 \%$ to $2.22 \%$ (Fig 5). The protein and ash content of shrimp shells during demineralization followed by deproteination process during microbiological chitin extraction are shown (Fig 6). Fermented shrimp shells composition resulted from different fermentation methods: deproteination followed by demineralization (DP-DM), and demineralization followed by deproteination (DM-DP) are compared (Fig 7).

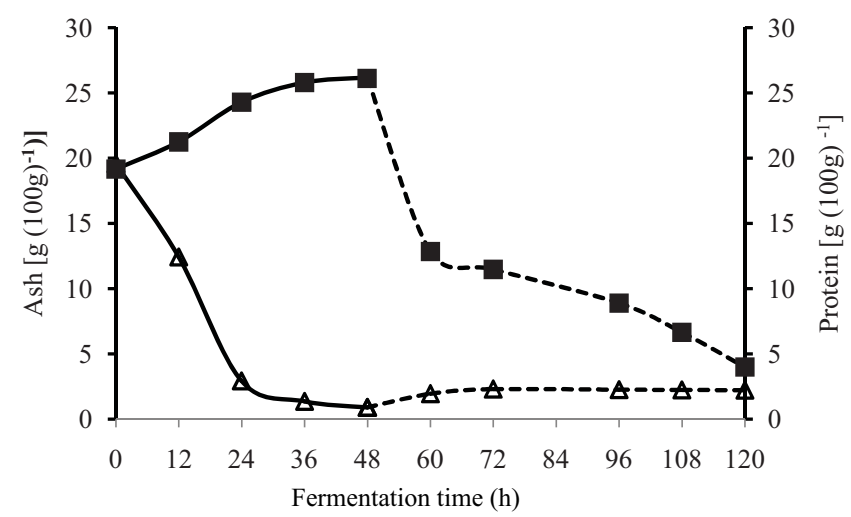

Fig 6 Ash and protein content in the shrimp shells during demineralization deproteination followed by process. —, demineralization; ---, deproteination; $\mathbf{m}$, protein; $\Delta$, ash.

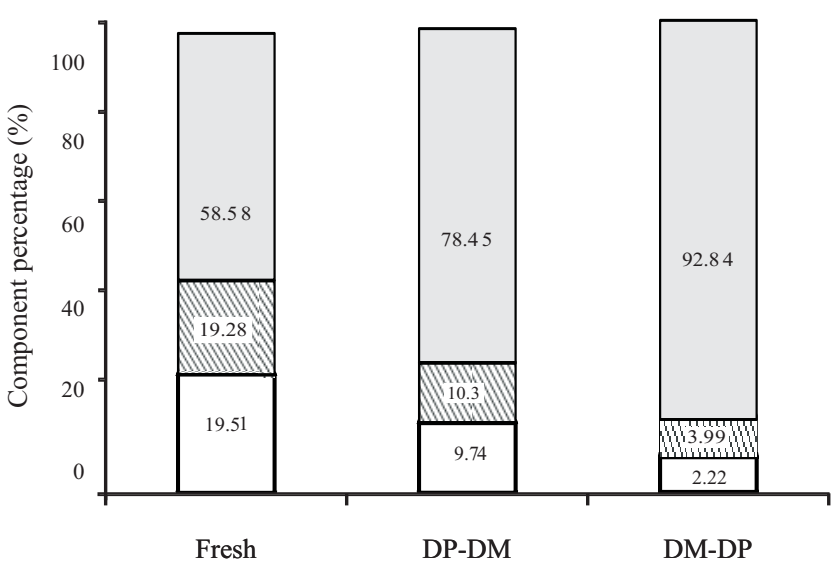

Fig 7 Comparison of fermented shrimp shells composition resulted from different fermentation methods. DP-DM: deproteination followed by demineralization, DM-DP: demineralization followed by deproteination. $\square$, chitin; $\mathbb{\mathbb { }}$, protein; $\square$, ash. 


\section{DISCUSSION}

Based on previous studies optimal agitation for demineralization using L. acidophilus FNCC 116 is 50 $\mathrm{rpm}$ and optimal agitation and aeration for deproteination using B. licheniformis F11.1 are 250 rpm and $2.5 \mathrm{vvm}$ respectively (Junianto et al. 2009). The aim of this study was to determine the succession of chitin extraction steps from shrimp shells. The first experiment was deproteination of fresh shrimp shells followed by demineralization of the deproteinated shells. The second experiment was demineralization of fresh shrimp shells followed by deproteination of the demineralized shells. In the first experiment, the fresh shrimp shells were fermented using $B$. licheniformis F.11.1 for $60 \mathrm{~h}$. The cell concentration as well as the protease production reached their maximum after $36 \mathrm{~h}$ (Fig 1). The initial protein content of the shells was $19.17 \%$ (dryweight). Due to the protease activity during the deproteination process, the protein content of the shells decreased down to 5.54\% (dryweight) (Fig 3 ). The main solid components in the shrimp shells are insoluble protein, chitin and minerals. In the deproteination process only protein was enzymatically hydrolyzed whereas chitin and minerals (ash) contents showed only minor changes. In the closed system (fermentation jar) the solid dry matters of shrimp shells were constant, if the insoluble protein was solubilized, and the ash and chitin content were intact, then the total amount of solid dry matter was decreased. As a result the percentage of ash in the shells increased from $19.57 \%$ (dryweight) up to $26.21 \%$ (dryweight) (Fig 3).

In the first experiment, after deproteination shrimp shells were demineralized. The experimental result (Fig 2) shows that the cell growth entered stationary state after $12 \mathrm{~h}$ of fermentation. The glucose was consumed rapidly during the first $24 \mathrm{~h}$ and lactic acid content in the broth increased rapidlyduring this time. During the demineralization process ash content decreased from $18.5 \%$ to $10.3 \%$ at the end of $48 \mathrm{~h}$ fermentation (Fig 3). However, the protein percentage of the shrimp shells increased from $5.54 \%$ to $10.3 \%$. Based on the data, it seems that L. acidophilus FNCC116 hardly produced proteolytic enzyme, and mainly produced lactic acid. L. acidophilus belongs to the homofermentative lactic acid bacteria that is able to convert the majority of glucose into lactic acid (Sanders and Klaenhammer 2001). As a result the main product in the demineralization process was lactic acid which would react with the calcium carbonate component in the chitin fraction of the shrimp shells to form calcium lactate (Rao and Stevens 2005). The bacterium used only produced very little protease $\left(0.011 \mathrm{U} \mathrm{mL}^{-1}\right)$, therefore the activity of the enzyme on shrimp shell protein was undetectable. This might be the reason why the protein content of the shrimp shells increased during the course of the demineralization (Fig 3). After the demineralization of deproteinated shrimp shells was completed, the ash, protein and chitin content of the fermented product were 9.74, 10.3, and $78.5 \%$ (dry weight) respectively (Fig 7). The deproteination process reduced the protein content of the shrimp shells from 19.57 down to $10.3 \%$ (efficiency of the protein removal was $47.37 \%$ ). The demineralization process reduced the ash content of the shrimp shells from $19.17 \%$ down to $9.74 \%$ (efficiency of the ash removal was $50.23 \%$ ). In the second chitin extraction process demineralization was followed by deproteination. Fig 4 shows cell growth, glucose consumption, lactic acid production and $\mathrm{pH}$ of fermented broth during the demineralization process using L. acidophilus FNCC 116. The amount of the cells increased rapidly during $12 \mathrm{~h}$ of fermentation and the stationary stage lasted for the following $24 \mathrm{~h}$. After that the cell amount decreased slowly. The glucose was consumed very fast during the first $24 \mathrm{~h}$ and seemed to be converted into lactic acid as shown by the rapid decrease of $\mathrm{pH}$ from 6.9 to 4.4 during the first $24 \mathrm{hs}$. Later the $\mathrm{pH}$ decreased slowly until the end of the process was reach after $24 \mathrm{~h}$ to $\mathrm{pH} 4.1$.

The second experiment led to a higher mineral and protein removal than the first experiment (Fig 3 and 6). Shrimp shells matrix is formed mainly of chitin and protein hardened by mineral salts especially calcium carbonate (Beaney et al. 2005). L. acidophilus mainly produced lactic acid by breaking down glucose creating lactic acid thereby lowering the $\mathrm{pH}$ of the fermentation broth and suppressing spoilage by microbial growth. The lactic acid reacted with calcium carbonate in the chitin fraction to form calcium lactate which is soluble and could be removed by washing. The following process was hydrolyzing protein in the chitin by fermentation of the proteolytic bacterium B. licheniformis F11.1. The proteolytic enzyme production increased along with the increase of cell concentration and reached the maximum activity after $48 \mathrm{~h}$ fermentation; however, the protein content was reduced drastically for the first $12 \mathrm{~h}$ of fermentation and decreased slowly for the rest of the fermentation time (Fig 5). The removal of protein content in the shrimp shells in the second process was higher since the calcium carbonate had been 
removed, the proteolytic enzyme could contact more easily with the protein in the chitin fraction of the shells. The chitin extraction process by demineralization followed by deproteination was done for $108 \mathrm{~h}$ or 4.5 days. The protein content of the shrimp shells was reduced from $19.57 \%$ down to $3.99 \%$ or $79.61 \%$ protein removed. The ash content was reduced from $19.51 \%$ down to $2.22 \%$ or $88.65 \%$ ash removed. (Fig 7). Daum et al. (2007) used the wild strain of $B$. licheniformis F11 and different species of Lactobacillus sp. After 5.5 days, the protein and ash removed were $95 \%$ and $89.6 \%$ respectively with $2.12 \%$ protein and $2.08 \%$ ash. The slightly better results of Daum et al 2007 even with the wild type strain might be the fact that the fermentor used was equipped with a commercial Ruskton impeller stirring system instead of the much simpler design of impeller stirring system used in this work. The different design of impeller might result in different agitation and aeration effect to the fermentation system and the fermentation process was longer (5.5 days) than this experiment( 4.5 days).

L. plantarum 541, which produces lactic acid and protease was used by Rao and Stevens (2005) for demineralization and deproteination in a one step fermentation of shrimp biowaste in a drum reactor and a beaker. The efficiency of deproteination and demineralization in the drum reactor were 66 and $63 \%$ respectively and in the beaker 54 and 52\% respectively. The $\mathrm{pH}$ was maintained at $\mathrm{pH} 6$ by adding acetic acid during the experiment within $24 \mathrm{~h}$.

These experiments showed two steps chitin extraction process which was demineralization process using lactic acid bacterium followed by deproteination process using proteolytic producing bacterium (this work and Daum et al. 2007 report) gave a better protein and ash removal than that of one step protein and ash removal done by Rao and Steven (2005).

To get a more efficient process for protein and ash removal that could be applied in larger scale, further works have to be done to improve the process. The efficiency of bacterial fermentation depends on factors such as quantity of inoculums, initial $\mathrm{pH}$, $\mathrm{pH}$ during the fermentation and fermentation time. Further experiments will be done to optimize the conditions of the demineralization and deproteination process.

To conclude, demineralization (DM) followed by deproteination (DP) of shrimp shells gave a higher chitin extraction efficiency than carrying out the process steps in opposite order (DP-DM). The DM-DP process removed $79.61 \%$ protein and $88.65 \%$ ash as compared to $47.37 \%$ protein and $50.23 \%$ ash removed by the DP-DM process.

\section{REFERENCES}

AOAC. 1984. Official Methods of Analysis. $15^{\text {th }}$ ed. Arlington,Virginia: Association of Official Analytical Chemistry. Inc.

Beaney P, Lizardi-Mendoza J, Healy M. 2005. Comparison of chitins produced by chemical and bioprocessing methods. J Chem Technol Biotechnol. 80:145-150. doi: 10.1002/jctb.1164.

Bustos RO, Healy MG. 1994. Microbial/enzymatic deproteination of Prawn Shell Waste. In: Proceeding Icheme Research Event; 1994 January 4-6, London.1994, p: 126-128.

Daum G, Stöber H, Veltrup K, Meinhardt F, Bisping B. 2007. Biotechnological process for chitin recovery out of shrimp wast. J Biotechnol. 131(1):S188

Dhewanto M, Kresnowati MTAP. 2002. Chitosan Industry: An alternative for maritime industry in empowerment Indonesia. In: Proceedings of Indonesian Student Scientific Meeting; 2002 October 4-6; Berlin, Germany. ISTEC-Europe. P: 327-333.

Gagne N, Simpson BK. 1993. Use of proteolytic enzyme to facilitate the recovery of chitin from shrimp waste. Food Biotechnol. 7(3):253263.

Healy M, Green A, and Healy A. 2003. Bioprocessing of marine crustacean shell waste. Acta Biotechnol.23 (2-3):151 - 260. doi: 10.1002/abio.200390023.

Hoffman K, Daum G, Köster M, Kulicke WM, Meyer-Rammes H, Bisping B, Meinhardt F. 2010. Genetic improvement of Bacillus licheniformis strains for efficient deproteinization of shrimp shells and production of high-molecular-mass chitin and chitosan. Appl Environ Microbiol. 76 (24):8211-8221.

Junianto, Mangunwidjaja D, Suprihatin, Mulyorini, Wahyuntari B. 2009. [Effect of aeration and agitation rate on protein hydrolysis of shrimp shells in microbiological chitin extraction] [in Indonesia]J. Bionatura. 11(2):107-117

Lowry OH, Roseborough NJ, Farr AL, Rundall RJ. 1951. Protein measurement with Folin Phenol Reagent. J Biol Chem. 193(1):265275.

Miller GM. 1959. Use of dinitrosalicylic acid reagent for determination of reducing sugars. Anal Chem. 31(3):426-428. doi: 10.1021/ac60147a030.

Oh YS, Shih IL, Tzeng YM, Wang SL. 2000. Protease produced by Pseudomonas aeruginosa K-187 and its application in the deproteinization of shrimp and crab shell waste. Enzyme Microbiol Technol. 27(1-2):3-10. doi:10.1016/S0141-0229(99) 00172-6.

Rao MS, Munoz J, Stevens WF. 2000. Critical factors in chitin production by fermentation of shrimp biowaste. Appl Microbiol Biotechnol. 54(6):808-813

Rao MS, Stevens WF. 2005. Chitin production by Lactobacillus fermentation of shrimp biowaste in a drum bioreactor and its chemical conversion to chitosan. J Chem Technol Biotechnol. 80(9):1080-1087. doi: $10.1002 /$ jetb. 1286

Rao MS, Stevens WF. 2006. Fermentation of shrimp biowaste under different salt concentrations with amylolytic and non-amylolytic Lactobacillus strains for chitin production. Food Technol Biotechnol. 44(1):83-87.

Rinaudo M. 2006. Chitin and chitosan:properties and application. Prog Polym Sci. 31(7):603-632.

Sanders ME, Klaenhammer TR.2001. Invited review: the scientific basis of Lactobacillus acidophilus NCFM functionality as a probiotic". 
J Dairy Sci. 84(2):319-331. doi: 10.3168/jds.S0022-0302(01) 74481-5.

Waldeck J, Daum G, Bisping B, Meinhardt F. 2006. Isolation and molecular characterization of chitinase-deficient Bacillus licheniformis strains capable of deproteiniation of shrimp shell waste to obtain highly vicous chitin. Appl Environ Microbiol. 72(12):7879-85. doi: 10.1128/AEM.00938-06.

Yang JK, Shih IL, Tzeng YM, Wang SI. 2000. Production and purification $\mathrm{f}$ protease from Bacillus subtilis that deproteinize crustacean waste. Enzyme Microbiol Technol. 26(5-6):406-413. 